\title{
Longtail Tuna (Thunnus tonggol) Consumption Frequency in Terengganu, Malaysia
}

\author{
Norhazirah Abdul Aziz', Adiana Ghazali1, Kamaruzzaman Bin Yunus², \\ Zurahanim Fasha Annual33, Ali Ahmad4, Ong Meng Chuan1,5,6* \\ ${ }^{1}$ Faculty of Science and Marine Environment, Universiti Malaysia Terengganu, Kuala Nerus, Malaysia \\ ${ }^{2}$ Kulliyyah of Science, International Islamic University Malaysia, Kuantan, Malaysia \\ ${ }^{3}$ Environmental Health Research Centre, Institute for Medical Research, Kuala Lumpur, Malaysia \\ ${ }^{4}$ Marine Fishery Resources Development and Management Department, Southeast Asian Fisheries Development Center \\ (SEAFDEC), Chendering, Malaysia \\ ${ }^{5}$ Institute of Oceanography and Environment, Universiti Malaysia Terengganu, Kuala Nerus, Malaysia \\ ${ }^{6}$ Ocean Pollution and Ecotoxicology (OPEC) Research Group, Universiti Malaysia Terengganu, Kuala Nerus, Malaysia \\ Email: *ong@umt.edu.my
}

How to cite this paper: Aziz, N.A., Ghazali, A., Yunus, K.B., Annual, Z.F., Ahmad, A. and Chuan, O.M. (2020) Longtail Tuna (Thunnus tonggol) Consumption Frequency in Terengganu, Malaysia. Open Journal of Marine Science, 10, 141-148.

https://doi.org/10.4236/ojms.2020.103011

Received: May 2, 2020

Accepted: May 31, 2020

Published: June 3, 2020

Copyright $\odot 2020$ by author(s) and Scientific Research Publishing Inc. This work is licensed under the Creative Commons Attribution International License (CC BY 4.0).

http://creativecommons.org/licenses/by/4.0/ (c) (i) Open Access

\begin{abstract}
In Terengganu, Longtail tuna or Thunnus tonggol is one of the most popular marine fishes landed by fishermen and has a high demand among customers. This species often served with a unique local delicacy called Nasi Dagang and Ikan Singgang, one of the favourite meals during breakfast by local communities. Since people have always consumed this species, therefore this study aims to identify the consumption rate of this species among Terengganu people. Specifically, this survey data obtained from 124 respondents, ages ranged from 15 to 60 years old from five districts in Terengganu, including Besut, Kuala Nerus, Kuala Terengganu, Hulu Terengganu, and Kemaman. Generally, the estimated amount of this species consumption is $239.7 \mathrm{~g}$ per person and 1.83 times per week. From the formula calculated, the amount of this species consumed by one person is $437.4 \mathrm{~g} /$ person/week. This value can use to calculate the permissible tolerable weekly intake (PTWI) to estimate the intake of pollutants, such as heavy metals in the human body.
\end{abstract}

\section{Keywords}

Thunnus tonggol, Consumption, South China Sea, PTWI

\section{Introduction}

In the year 2020, the Food and Agriculture Organization predicted that the global supply of seafood would be deprived of by about 23 million tons to main- 
tain at least the current consumption level $(18.4 \mathrm{~kg})$ of the per-capita of seafood [1]. In line with the global norm, Malaysia is also faced with insufficiency supply due to the high demand for fisheries stock and declining in capture fisheries production in this country [2] [3]. Today, annual per-capita of seafood consumption of Malaysians ranked number fifth throughout the world and second highest among Asian nations after Japan [4]. Terengganu is one of the fish landing centers in Malaysia that supply fisheries stock to other areas in Malaysia. However, the annual fisheries landing in Terengganu have decreased for the past five years, and Longtail tuna (Thunnus tonggol) is one of the species that had been affected by the declining pattern in landing statistics by Department of Fisheries Malaysia [5]. The number of this species landed from 2015 has been decreased by $17.2 \%$ to 375.5 ton metric in 2018 (Figure 1).

Thunnus tonggol, known as Ikan Tongkol by local (Figure 2) is a commercially important pelagic species that found abundantly in tropical to temperate neritic habitat throughout the Indo-Pacific [6] [7]. It can reach a maximum

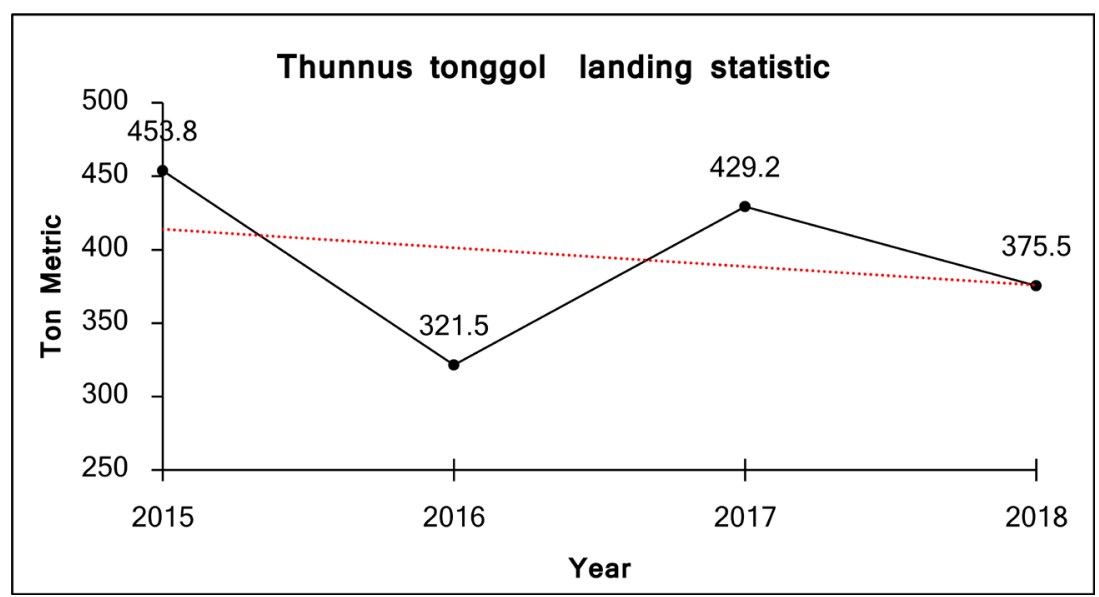

Figure 1. The annual Thunnus tonggol landing statistic in Terengganu from the year 2015 to 2018 decreased by $17.2 \%$ of ton metric (DOF, 2019).

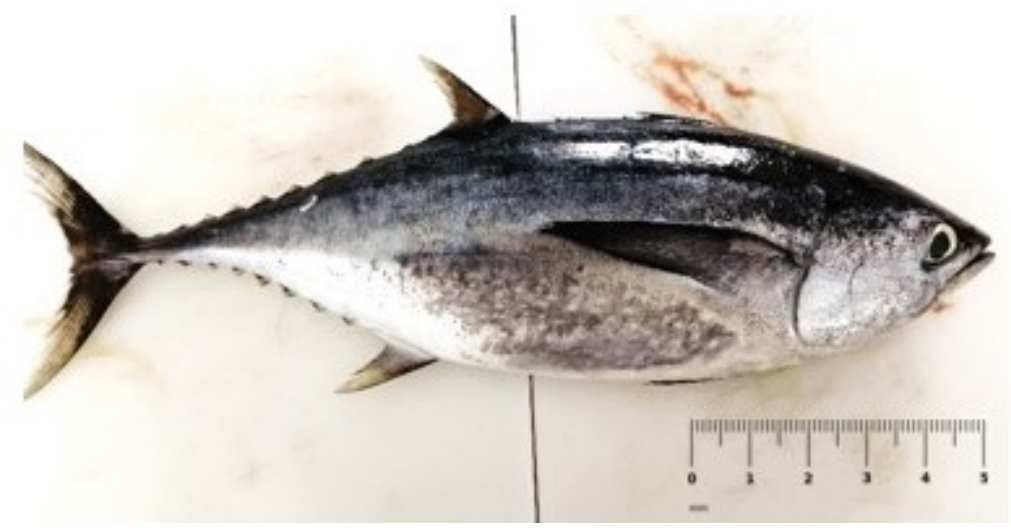

Figure 2. Longtail tuna or Thunnus tonggol is a relatively smallest size among tuna species group. They are known as pelagic species that avoid very turbid waters and areas with reduced salinity such as estuaries. 
length of 1.5 meters and up to 32 kilograms in weight [8] [9]. The lower side and belly are of silvery-white colour, with colourless elongate oval spots arranged in horizontally oriented rows [10] [11]. In Terengganu, this species is one of the most popular commercial marine fishes that commonly serve breakfast and lunch meals. Nasi Dagang and Ikan Singgang are two famous menus in Terengganu that use this species as a main ingredient in the dish.

\section{Materials and Methods}

A survey has conducted from April to September 2019. A total of five districts in Terengganu (Figure 3) have been selected as the survey area, including Besut, Kuala Nerus, Kuala Terengganu, Hulu Terengganu, and Kemaman which involve 124 respondents, and age ranged from 15 to 60 years old. For a survey design, all available information on the consumption of Thunnus tonggol among Terengganu people has considered. Generally, the survey questionnaire was composed of two sections: 1) Personal information including the age and residential districts, 2) questions on consumption behaviours including the amount intake and the frequency of this species.

\section{Results and Discussion}

The survey was administered randomly to the residents aged between 15 and 60

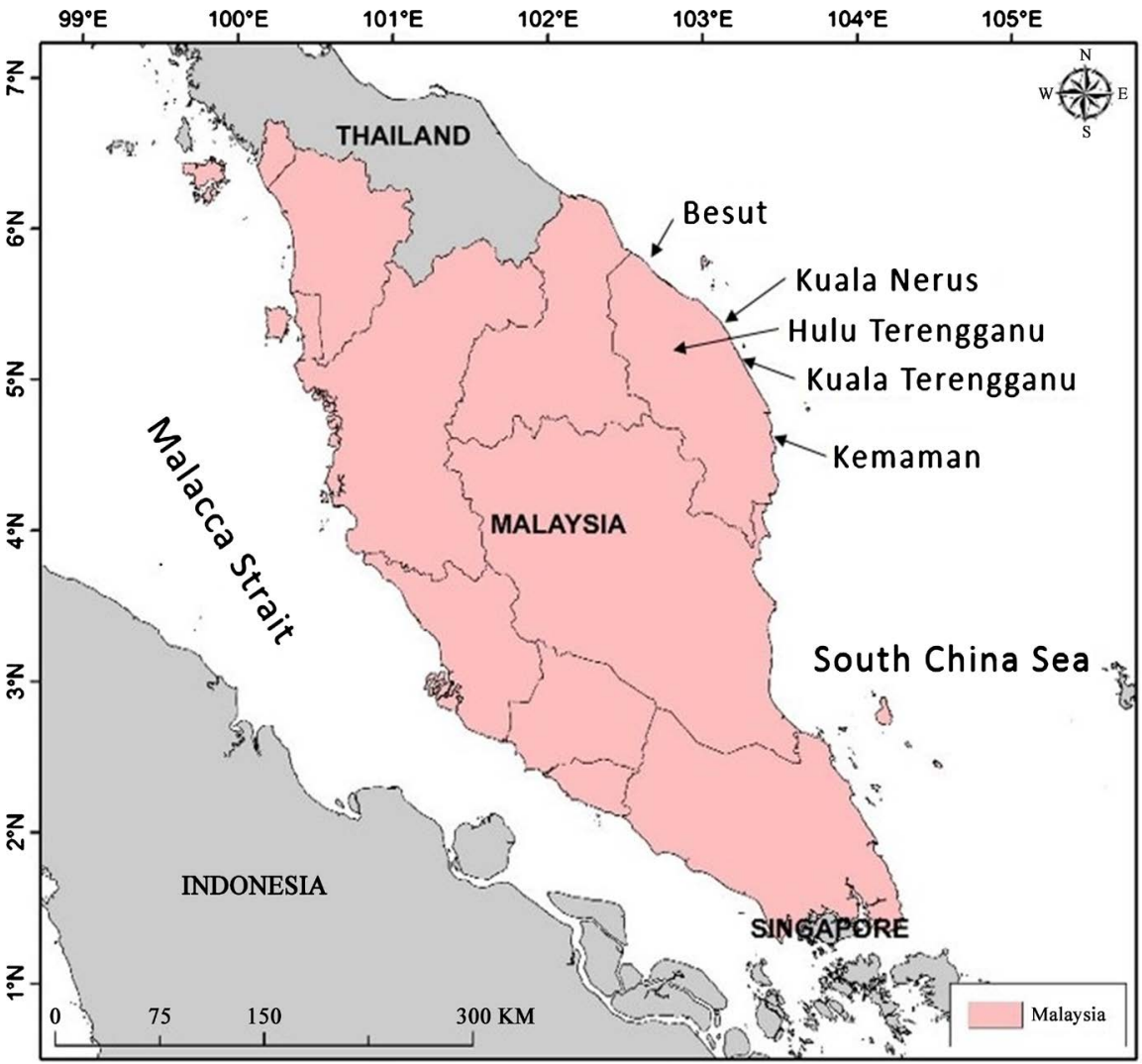

Figure 3. Terengganu is one of state in Peninsular Malaysia and a part of the South China Sea and one of the significant fish landing centers in Malaysia. 
years old. Through the survey, $42.9 \%$ of respondents were aged from 15 to 24 years old, while the least respondents came from aged 35 to 44 years old. Among these, $78.6 \%$ of respondents were female, and $21.4 \%$ of respondents were male.

Table 1 describes the variables and the definition of the question in the questionnaire set. Based on the survey question, one important question referring to Thunnus tonggol consumption frequency is "How often did you consume Thunnus tonggo?" Given that the level of consumption frequency encoded as

Table 1. Variables and the definition of the question used in the questionnaire set.

\begin{tabular}{|c|c|c|}
\hline Variables & Description & Percentage \\
\hline \multirow[t]{2}{*}{ Gender } & Male & $21.4 \%$ \\
\hline & Female & $78.6 \%$ \\
\hline \multirow{4}{*}{$\begin{array}{l}\text { Age } \\
4 \text { ranges of age }\end{array}$} & $15-24$ years old & $42.9 \%$ \\
\hline & 25 - 34 years old & $17.1 \%$ \\
\hline & 35 - 44 years old & $10.0 \%$ \\
\hline & 45 - 60 years old & $30.0 \%$ \\
\hline \multirow{5}{*}{$\begin{array}{c}\text { Area } \\
5 \text { different districts in Terengganu state }\end{array}$} & Besut & $22.2 \%$ \\
\hline & Kuala Nerus & $16.2 \%$ \\
\hline & Kuala Terengganu & $22.2 \%$ \\
\hline & Hulu Terengganu & $20.5 \%$ \\
\hline & Dungun/Kemaman & $18.8 \%$ \\
\hline \multirow{6}{*}{$\begin{array}{c}\text { Frequency } \\
7 \text { indicators variables }\end{array}$} & Twice a week & $16.2 \%$ \\
\hline & Once a week & $26.6 \%$ \\
\hline & Twice a month & $19.7 \%$ \\
\hline & Once a month & $21.4 \%$ \\
\hline & Once in 6 months & $10.3 \%$ \\
\hline & Others & $4.3 \%$ \\
\hline \multirow{5}{*}{$\begin{array}{l}\text { Amount of fish meal intake } \\
\text { (Estimation in gram based on slice of fish } \\
\text { flesh) }\end{array}$} & $141 \mathrm{~g}$ & $11.4 \%$ \\
\hline & $196 \mathrm{~g}$ & $37.7 \%$ \\
\hline & $272 \mathrm{~g}$ & $9.6 \%$ \\
\hline & $392 \mathrm{~g}$ & $10.5 \%$ \\
\hline & $402 \mathrm{~g}$ & $30.7 \%$ \\
\hline \multirow{3}{*}{$\begin{array}{l}\text { Customer preferences on fish parts } \\
\text { e.g.: Head, muscle, tail. }\end{array}$} & Head & $32.8 \%$ \\
\hline & Muscle & $47.4 \%$ \\
\hline & Tail & $19.8 \%$ \\
\hline \multirow{4}{*}{$\begin{array}{l}\text { Cooking methods } \\
\text { The methods applied to cook the fish }\end{array}$} & Grilled & $2.6 \%$ \\
\hline & Boiled & $51.3 \%$ \\
\hline & Fried & $31.3 \%$ \\
\hline & Steamed & $14.8 \%$ \\
\hline
\end{tabular}


an ordered response, it has divided into six categories. For example, $26.6 \%$ of respondents answered that they consumed once a week, and $10.3 \%$ of them were likely to eat this species once in six months (Figure 4).

The survey also asked about the fish part that respondents opt (Figure 5). The poll showed that only $19.0 \%$ of respondents chose fish tail part, and $32.8 \%$ chose fish heads. Majority of the respondents (47.4\%) were likely to take muscle parts in their dish. Meanwhile, in terms of cooking methods, $51.3 \%$ of respondents prefer boiling methods, while $31.3 \%$ prefer frying, $14.8 \%$, and $2.6 \%$ preferable steaming and grilling techniques, respectively (Figure 6).

Table 2 presents the calculated average data on the amount and frequency of Thunnus tonggol intake by Terengganu people. The average dietary of this species was $239.7 \mathrm{~g}$ per person in one day, while the average frequency was 1.8 times per week. Hence, the estimation of average this species consumption was 437.5 g/person/week.

In Malaysia, fish has always been a superior choice of protein source for most

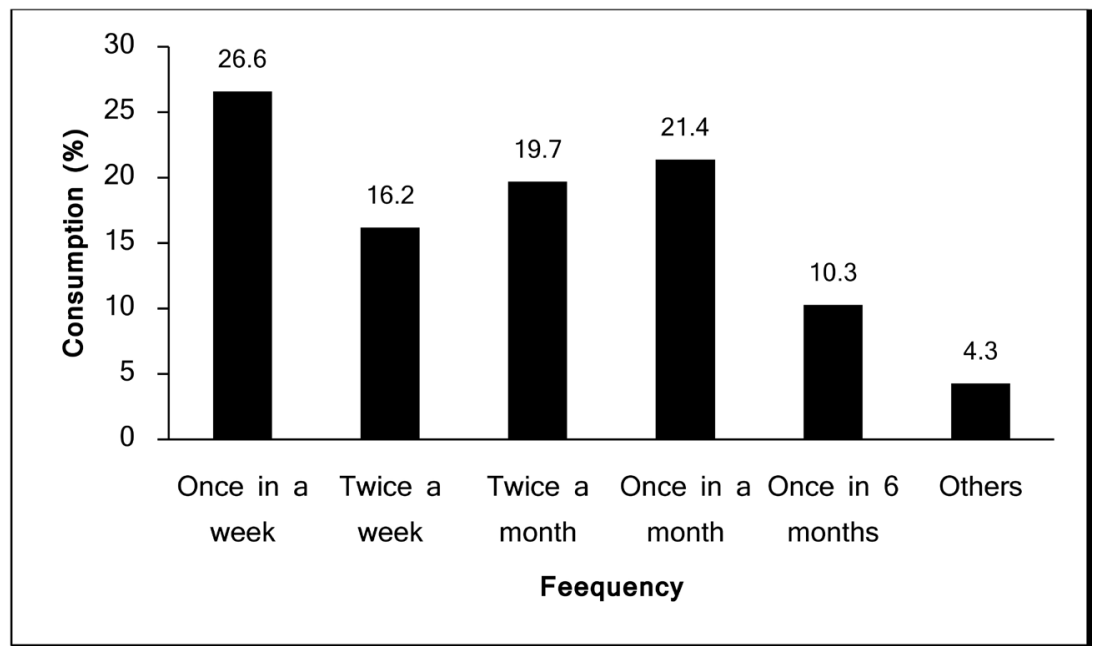

Figure 4. Frequency of Thunnus tonggol consumption by Terengganu people.

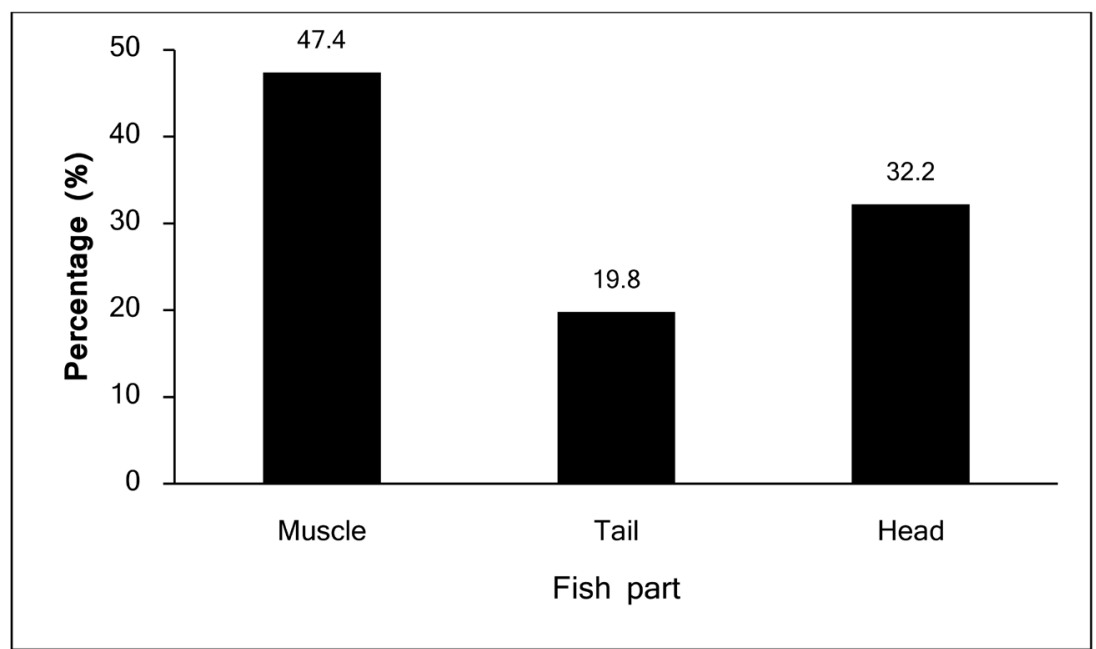

Figure 5. Respondent's fish part opt for Thunnus tonggol. 


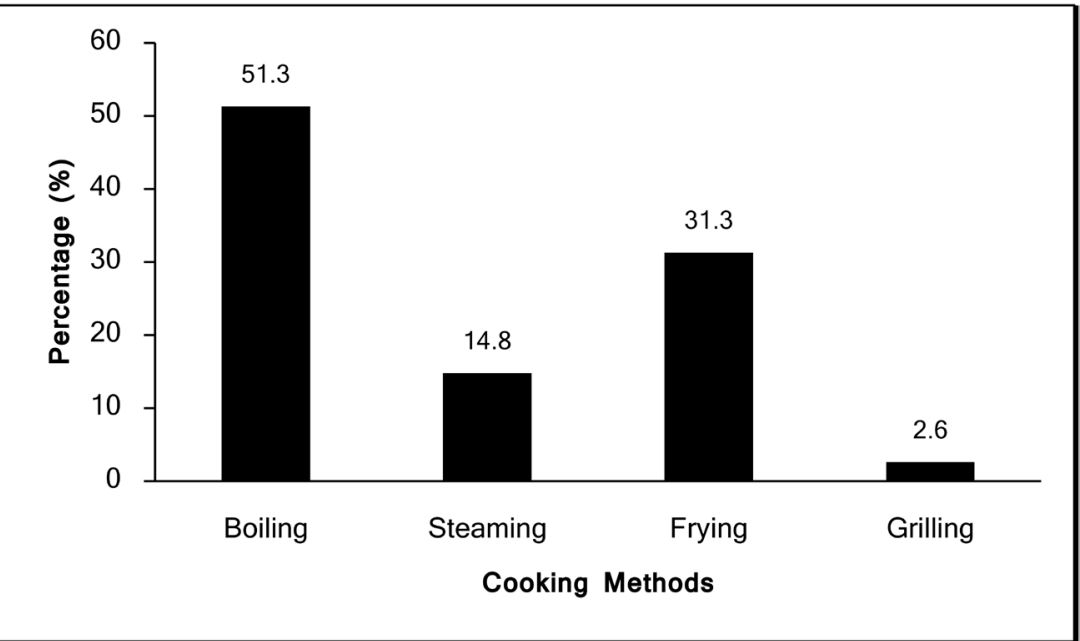

Figure 6. Respondents favourite cooking methods for Thunnus tonggol.

Table 2. The average consumption on Thunnus tonggol among Terengganu people.

\begin{tabular}{ccc}
\hline Average amount $(\mathrm{g})$ & $\begin{array}{c}\text { Average frequency } \\
\text { (times/week) }\end{array}$ & $\begin{array}{c}\text { Average consumption }(\mathrm{g}) / \\
\text { person/week }\end{array}$ \\
\hline 239.7 & 1.8 & 437.4 \\
\hline
\end{tabular}

of the population compared to other sources such as chicken and beef [12]. Particularly, a totality of $26.6 \%$ Terengganu people used to take this species as their meal at least once in a week. The finding indicates that this species has a higher demand in this region. Apart from that, this species also considered as the most economical and can be bought at an affordable price [13]. Furthermore, by eating fish, it is believed that can help to prevent heart disease [14] [15] and reduce the level of cholesterol [16] due to the fish characteristic that can accommodate an essential fatty acid, docosahexaenoic acid and eicosapentaenoic acid in their tissue [17]. From the consumption rate calculated, the average amount of this species consumption per person in one week is $437.4 \mathrm{~g}$. This finding was slightly higher than the study conducted past 10 years by Irwandi and Faridah [18], which is $0.06 \mathrm{~kg} /$ person/day or $420 \mathrm{~g} /$ person/week.

A comparative survey among different cooking methods apply to this species was also asked the respondents. Data from survey findings show $51.3 \%$ of the respondents choose to boil the fish as their preferred cooking method. This method corresponds with the famous menus in Terengganu, which the fish is cooked with curry gravy and serves with glutinous rice, namely Nasi Dagang and Ikan Singgang, fish soup with added turmeric, chilli, garlic, and onion. Concerning the preference fish parts, $47.4 \%$ of respondents favour muscle part, which is the major edible part of the fish. The fish muscle shares sufficient balanced amino acids, savoury flavour, and high digestibility [19]. Hence, it becomes the most popular and suitable source of protein to the healthy adult and children or even for the patient that suffers from inflammation and in the process of wound healing that satisfies the need for amino acid requirements [20]. 


\section{Conclusion}

The consumption rate of Thunnus tonggol in Terengganu has increased due to the high population growth rate and a major source of animal protein due to the stability and lower cost compared to meat. Nonetheless, the annual landing statistics for this species has decreased in the past five years. This study, in practical terms, indicated respondent's preference and consumption rate of this species in Terengganu, Malaysia. This finding can be used as a reference in calculating human permissible tolerable daily and weekly intake (PWTDI and PTWI) to estimate the intake of pollutants by consuming fish, especially by Thunnus tonggol for Terengganu and adjacent regions.

\section{Acknowledgements}

This research has conducted with the funding from the Faculty of Science and Marine Environment and INOS under Higher Institution Centre of Excellence (HICoE, 66928), Universiti Malaysia Terengganu. First of all, the authors wish to acknowledge their gratitude to the anonymous reviewers who gave freely time and effort, constructive recommendations that enhanced the value of this manuscript. The authors wish to express their gratitude to all the selected respondents in Terengganu that have participated in this survey.

\section{Conflicts of Interest}

The authors declare no conflicts of interest regarding the publication of this paper.

\section{References}

[1] FAO (2012) The State of World Fisheries and Aquaculture. Food and Agriculture Organization of the United Nations, Rome.

[2] Islam, G.M.N., Tai, S.Y., Noh, K.M. and Noh, A.F.M. (2014) Community's Perspectives towards Marine Protected Area in Perhentian Marine Park, Malaysia. Open Journal of Marine Science, 4, 51-60. https://doi.org/10.4236/ojms.2014.42007

[3] Arai, T. (2015) Diversity and Conservation of Coral Reef Fishes in the Malaysian South China Sea. Reviews in Fish Biology and Fisheries, 25, 85-101. https://doi.org/10.1007/s11160-014-9371-9

[4] York, R. and Grossard, M.H. (2004) Cross-National Meat and Fish Consumption: Exploring the Effects of Modernization and Ecological Context. Ecological Economics, 48, 293-302. https://doi.org/10.1016/j.ecolecon.2003.10.009

[5] DOF, Department of Fisheries Malaysia (2019). https://www.dof.gov.my/index.php/pages/view/82

[6] Griffiths, S.P. (2010) Stock Assessment and Efficacy of Size Limits on Longtail Tuna (Thunnus tonggoI) Caught in Australian Waters. Fisheries Research, 102, 248-257. https://doi.org/10.1016/j.fishres.2009.12.004

[7] Kunal, S.P., Kumar, G., Menezes, M.R. and Meena, R.M. (2014) Genetic Homogeneity in Longtail Tuna Thunnus tonggol (Bleeker, 1851) from the Northwest Coast of India Inferred from Direct Sequencing Analysis of the Mitochondrial DNA D-Loop Region. Marine Biology Research, 10, 738-743. 
https://doi.org/10.1080/17451000.2013.852682

[8] Al-Mamari, D., Al-Kharusi, L., Al-Kiyumi, F., Al-Shogebai, S., Al-Anboori, I., Al-Seneadi, R. and Khrorv, S. (2014) Record of the Largest Longtail Tuna, Thunnus tonggol (Bleeker 1851) from Offshore Salalah in the Sultanate of Oman. Journal of Fisheries, 2, 215-216. https://doi.org/10.17017/jfish.v2i3.2014.57

[9] Kumar, V., Mali, K.S., Farejiya, M.K. and Rao, R. (2017) Growth, Age and Mortality of Thunnus tonggol(Bleeker, 1851) Exploited along the North West Coast of India. European Journal of Biotechnology and Bioscience, 5, 1-5.

[10] Joshi, K.K., Abdussamad, E.M., Said Koya, K.P., Prathibha, R., Ghosh, P., Elayathu, M.N.K., Prakasan, D., Manju, S., Beni, N. and Syda, R.G. (2012) Taxonomy and Key for the Identification of Tuna Species Exploited from the Indian EEZ. Indian Journal of Fisheries, 59, 53-60.

[11] FAO (1983) An Annotated and Illustrated Catalogue of Tunas, Mackerels, Bonitos and Related Species Known to Date. FAO Fisheries Synopsis No. 125, Volume 2, 137.

[12] Zurahanim, F.A., Maher, W., Krikowa, F., Hakim, L., Ahmad, N.I. and Foster, S. (2018) Mercury and Risk Assessment from Consumption of Crustaceans, Cephalopods and Fish from West Peninsular Malaysia. Microchemical Journal, 140, 214-221. https://doi.org/10.1016/j.microc.2018.04.024

[13] Prasertsan, P. and Prachumratana, T. (2008) Comparison and Selection of Protease and Lipase Sources from Visceral Organs of Three Tuna Species. Songklanakarin Journal of Science and Technology, 30, 73-76.

[14] Sinclair, A.J. (1993) The Nutritional Significance of Omega-3 Polyunsaturated Fatty Acids for Humans. Asian Food Journal, 8, 3-13.

[15] Stone, N.J. (1997) Fish Consumption, Fish Oil, Lipids and Coronary Heart Disease. American Journal of Clinical Nutrition, 65, 1083-1086. https://doi.org/10.1093/ajcn/65.4.1083

[16] Zamani, L., Givianrad, M.H., Ezzatpanah, H. and Bakhoda, H. (2015) Determination of Nickel and Chromium Content in Serum, Emulsion, Skin and Viscera of Iranian Tuna Fish. Indian Journal of Geo-Marine Sciences, 44, 1409-1414.

[17] Yagi, S., Fukuda, D., Aihara, K., Akaike, M., Shimabukuro, M. and Sata, M. (2017) n-3 Polyunsaturated Fatty Acids: Promising Nutrients for Preventing Cardiovascular Disease. Journal of Antherosclerosis and Thrombosis, 24, 999-1010. https://doi.org/10.5551/jat.RV17013

[18] Irwandi, J. and Faridah, O. (2009) Mineral and Heavy Metals Contents of Marine Fin Fish in Langkawi Islands, Malaysia. International Food Research Journal, 16, 105-112.

[19] Olumaniyi, O.O., Dosumu, O.O. and Awolola, G.V. (2010) Effect of Local Processing Methods (Boiling, Frying and Roasting) on the Amino Acid Composition of Four Marine Fishes Commonly Consumed in Nigeria. Food Chemistry, 123, 1000-1006. https://doi.org/10.1016/j.foodchem.2010.05.051

[20] Kim, J.D. and Lall, S.P. (2000) Amino Acid Composition of Whole-Body Tissue of Atlantic Halibut (Hippoglossus hippoglossus), Yellowtail Flounder (Pleuronectes ferruginea), Japanese Flounder (Paralichthys olivaceus). Aquaculture, 187, 367-373. https://doi.org/10.1016/S0044-8486(00)00322-7 